\title{
THE RESULTS OF MOLTING BEARING HENS
}

\author{
Danka Maslić-Strižak \\ Scientific Veterinary Institute of Serbia, 14 Vojvode Toze street, Belgrade, Serbia \\ maslicd@ikomline.net
}

\begin{abstract}
The swarm of Hy Line bearing hens ( 8260 pieces) held in three floor cages were molted at the age of 87 weeks. In the first producing season the swarm did not reach the planned weight and in 87 weeks the average weight of hens was 1768 grams. The reduced body weight caused a slightly smaller production than planned, so the production of eggs on each hen was 335 pieces, and the mass of the eggs on each hen was 20.9 kilos. The average daily meal was 133 grams. The swarm was healthy during the entire production period, and the deaths reached $4,8 \%$. The owner of hens decided to molt when the average production per week was $57.56 \%$, and the percentage of eggs with low quality reached $4.85 \%$. The intense molting was conducted according to a plan of restricting food, water and light, made especially for this swarm. The plan was also adjusted during the production period, because of the low temperatures outside and inside the object where hens were held. Molting lasted for six weeks, hens lost $22 \%$ of body weight, and the period of the second egg bearing lasted two weeks. In the second producing season $93 \%$ of the eggs was in SS, S and A weight category. Eggs with soft shell were reduced to $0,8 \%$, the amount of food spent per hen daily was 135 grams, during the six months long production, 170 eggs per hen were produced. Death during molting and production period in the second producing season was $6.4 \%$.
\end{abstract}

Key words: bearing hens; molting; producing eggs

\section{РЕЗУЛТАТИ ОД МИТАРЕЊЕ НА КОНСУМНИ НЕСИЛКИ}

Јато од 8260 несилки од Ну-линијата држени во кафезни транспортни батерии е митарено на возраст од 87 недели. Во првата производна сезона јатото не ја постигна предвидената телесна маса и во 87-та недела просечната маса на кокошките беше 1768 g. Намалената маса услови малку пониско производство од предвиденото според технологијата, така што производството на јајца по вселена кокошка беше 355 парчиња, а масата на јајцата по кокошка изнесуваше 20,9 kg. Просечен дневен оброк изнесуваше $133 \mathrm{~g}$. Во текот на целото производство јатото беше здраво, а угинувањата со шкартирање достигнаа 4,8\%. Држителот на кокошките се одлучил за митарење на јатото кога просечното неделно производство на јајца било 57,56\%, а процентот на јајца со лушпа со слаб квалитет достигнал 4,85\%. Форсираното митарење е спроведено според планот за редукција на храната, водата и осветлувањето направен за ова јато, а поради многу ниски надворешни температури, како и температурата во самиот објект, програмата е приспособувана во текот на работата. Митарењето траеше 6 недели, коковчињата изгубја $22 \%$ од телесната маса, а периодот на второто пронесување траеше 2 недели. Во втората производна сезона $93 \%$ од јајцата беа со тежинска категорија СС, С и А. Јајцата со мека лушпа се сведени на $0,8 \%$, потрошувачката на храна изнесуваше $135 \mathrm{~g}$ по една кокошка на ден, а во текот на шестмесечното производство се произведени 170 јајца по една кокошка. Угинувањето и шкартот во текот на митарењето и производството во втората производна сезона изнесуваше $6,4 \%$

Клучни зборови: несилки; митарење; производство на јајца.

\section{INTRODUCTION}

Molting is a natural process for birds that happens every year. In the course of molting, hens lose their old feathers, and grow new. The production of eggs stops during molting. Depending on the time when molting starts, we distinguish "late molters" and "early molters". Hens referred to as "late molters" will lay for 12 to 14 months before molting, while others, referred to as "early molters," may begin to molt after only a few months in 
production. Late molters are generally the better laying hens.

Induced or forced molting is a method that enables planning of egg production. Webster in his studies (Webster A. B., 2003) explores the physiology and the behaviour of hens during induced molting. The purpose of forced molting is to renew the reproductive system of hens and to carry out a complete rejuvenation.

The reproductive system of hens goes through a complete regression during molting and the production must stop. Due to the correlation between the reproductive system regression and the body weight loss, the program of molting we used here was based on the loss of body weight.

The producers choose to start with the induced molting because of commercial and economical reasons, when the egg price is low, and the hen price is high (D. D. Bell, 2003). Depending on the age of the flock when molting is implemented for the first time, it can be molted for two or three times.

By keeping flocks of two production seasons, the needs for the young hens are reduced for $47 \%$ because the lifetime of hens is extended. Farms that perform regular molting of hens, exploit 5.7 instead of 8.4 flocks in ten years. The most often method of induced molting is starvation.

The results achieved from the second production are at least $80 \%$ of production from the period before the molting, and sometimes better results are obtained than in the first production season.

\section{MATERIALS AND METHODS}

Molting was conducted in a manufacturing facility for bearing hens, with a capacity of 8640 pieces, and populated with 8574 pieces of eighteen weeks old hens.

Poultry was put in cages, each of them for five hens. There were 66 cages in total, each with 4 hens in it.

For this work, a flock of 8260 hens, 87 weeks old, was used.

Program for molting was made after weighing 200 hens out of 40 randomly selected cages.

Control weighing was performed only on hens from marked cages.

Housing lists were made daily (evidence of using food, water, egg production, deaths, length of light during the day, temperature).

Behaviour of poultry was followed during the entire period of work.

Each corpse went through a pathoanatomical examination.

By the end of production, weighing once a week, grit every three days, everything like in the first production season.

Table 1

Molting program

\begin{tabular}{|c|c|c|c|c|c|}
\hline \multirow{2}{*}{ Days } & \multirow{2}{*}{$\begin{array}{l}\text { Food } \\
(\mathrm{g} / \mathrm{hen})\end{array}$} & \multirow{2}{*}{ Water } & \multicolumn{2}{|c|}{ "Light (length and strength } & \multirow{2}{*}{ Remark } \\
\hline & & & (Hours) & $\left(\mathrm{W} / \mathrm{m}^{2}\right)$ & \\
\hline $1-4$. & No food & No water & Dark) & & $\varnothing$ \\
\hline $5-8$. & 25 & At will & 2 & 1 & $\varnothing$ \\
\hline 9. & 25 & At will & 2 & 1 & Weighing \\
\hline $10-15$. & 25 & At will & 4 & 1.5 & Weighing \\
\hline $16-18$. & 50 & At will & 6 & 1.5 & $\begin{array}{l}\text { On the 18th day blood tests for controlling titer and taking samples for } \\
\text { bacteriological examinations }\end{array}$ \\
\hline $19-25$. & 100 & At will & 8 & 1.5 & On the 25th day giving grit (rock) \\
\hline $26-30$. & 110 & At will & 8 & 1.5 & Vitamins \\
\hline $31-38$. & 115 & At will & 12 & 2.5 & Weighing on the 31 st day. Grit every three days \\
\hline $39-42$. & 120 & At will & 14 & 3.5 & Weighing \\
\hline $43-58$. & 125 & At will & 15 & 3.5 & \\
\hline
\end{tabular}




\section{RESULTS AND DISCUSSION}

The age of the flock has a large impact on the results of molting. According to the results of Carey (Carey et al, 1987) it is harder for younger flocks to stop the production and lose feathers. On the other hand, older flocks have smaller potential for renewal, and the quality of egg shells in the other production season is decreased.

We decided to induce molting in the $87^{\text {th }}$ week because of a reduced supply of hens on the market, and their high price. The production of eggs in the flock was $57.56 \%$, and there were $4.85 \%$ eggs with a weak, low quality shell. Before the molting started, the flock had $3.66 \%$ deaths, for 69 weeks in a cage. The production of eggs per hen was 335 pieces or $20.9 \mathrm{~kg}$ of egg masses. The average meal per day was $133 \mathrm{~g}$ of standard food mixture for bearing hens, with $16.5 \%$ proteins.

Weighing 200 hens from randomly selected and marked cages from different locations in the object, we found that the average weight was $1768 \mathrm{~g}$. That weight was lower than the one technologically anticipated for that category. Based on these values and because of the low temperatures in the facility, we decided that this flock needs a $25 \%$ maximum loss of weight. The starvation program was made based on this.

According to other studies (Leek et al., 1982; Ocak et al, 2004) the regression of the reproductive system and successful molting is possible with the loss of weight up to $35 \%$. The results of our studies (Maslić-Strižak et al, 1997, 1998) the loss of weight of $20-25 \%$ is sufficient for a successful production in the second production season.

In our program we predicted that the first four days chickens stay without food, water, and light. The length of period without food depends on the initial weight of hens before molting and on the accomodation of hens (Mingan et al, 1999), quality of the facility (with or without windows), season, etc. On the $5^{\text {th }}$ day we decided to provide $25 \mathrm{~g}$ of food and 2 hours of $1 \mathrm{~W} / \mathrm{m}^{2}$ light. In that way a slow loss of weight and a total cessation of load, with a regression of reproductive system were achieved. On the 9th day we checked the weight of hens again and noticed a loss of $18 \%$, meaning that a suitable program for this flock was applied.

The cessation of egg production on the 11th day was somewhat faster than other authors had (Baker et al., 1983), since in their studies a total cessation happened 14 to 17 days from the beggin- ing of molting. The difference that occured in our work is the result of the age of the flock when the molting started.

On the $15^{\text {th }}$ day, the loss of weight was $22 \%$, and the average weight was $1375.5 \mathrm{~g}$. The archieved weight was sufficient for the meals to increase to $50 \mathrm{~g}$ of food, and the light to 6 hours and 1.5 $\mathrm{W} / \mathrm{m}^{2}$. Due to large amounts of stress among hens, caused by a forced molting process, it is necessary to perform regular health controls, so we checked blood serums, with a method of enzyme - linked immunosorbent tests, for infectious bronchitis, plague and mycoplasma. The results were satisfasctory. Simultaneously, the flock was tested on salmonella, because according to the data from a previous study (Gary D. et al., 2011) it is a great risk for hens during molting.

The controls showed no health problems, so the preparations for bearing started without delay. To prevent the problems with weak quality of the egg shells, the hens received grit since the $25^{\text {th }}$ day. Brake (Brake et al., 1984) gave increased amounts of calcium - stone before the molting, but according to our results giving grit after the starvation period results in satisfying quality of egg shells in the second season. Meals were increased gradually, and on the $31^{\text {st }}$ day hens had an average weight of 1557 grams. By increasing the meals, the amount of light during the day was also extended, and it reached 8 hours with $1.5 \mathrm{~W} / \mathrm{m}^{2}$. On the $32^{\text {nd }}$ day we started the light stimulation by increasing it to 12 hours and $2.5 \mathrm{~W} / \mathrm{m}^{2}$, and the amount of food to 115 grams. With this program, the hens' weight was 1685.5 grams on the $39^{\text {th }}$ day, which is enough for an intensive production. The light was extended to 14 hours, and meals to 120 grams. On the $42^{\text {nd }}$ day, the egg production was $5 \%$. The length of the molting process is different in different flocks and it depends on external and internal factors. The rate of molting is affected by the environment temperature, low temperatures cause fast loss of weight which can lead to poor production in the second production season, and that is why it is necessary to control the weight of hens during the process and adjust the length of the program to it.

The body mass in the second production season has the same influence on the results of production as it had in the first one, and the quality and quantity of meals should be adapted to it. This flock had a higher average weight in the second production season than it had in the first one, dur- 
ing the removal of spoilage from the production it was 1896 grams.

In this work, molting lasted for 6 weeks (for 5 $\%$ of production), respectively 58 days until the peak of production. 3050 grams of food were used per hen until the first egg. The flock did not have health problems and during molting a total of $1.8 \%$ of hens were dead or rejected, and during the second production season deaths were $1.6 \%$.

The second production season lasted for 37 weeks and 170 eggs or $11.05 \mathrm{~kg}$ of eggs per hen were produced. Out of all produced eggs, in weight categories SS, S, and A were $93 \%$ of eggs, and there was $0.8 \%$ of eggs with low shell quality.

\section{CONCLUSIONS}

Molting is used to prolong the production life of hens, and it can be used on a healthy flock, adapted to the conditions in which that flock lives.

Molting makes it possible to obtain an egg with less investment.

In this flock, the amount of food spent for bringing it to the second production season was $47.88 \%$ of the food spent for raising an 18 weeks old hen.

Total deaths during molting and the second production season were $3.4 \%$.

The production of eggs in the second production season can reach to $94 \%$ of the first season.

The size and quality of eggs in the second production season are satisfactory.

\section{REFERENCES}

[1] A. B. Webster (2003): Physiology and behavior of the hen during induced molt, Poultryi Sci. 82: 992-1002

[2] A. Almond, P. Cransberg, R. Peacock, J. Goldsmith (1997): Evoluation of performance of hens fed high nutrient density diets post-moult. Rural industries researsh and development corporation.

[3] Baker, J. J., J. Brake and G. R. McDaniel (1983): The Relationship between Body Weight Loss during an Induced Molt to Postmolt Egg Production, Egg Weight, and Shell Quality in Caged Layers, Poultry Sci., 62: 409-413.

[4] Brake, J., J. D. Garlich and T. A. Carter (1984): Relationship of Dietary Calcium Level during the Prelay
Phase of an Induced Molt to Postmolt Performance. Poultry Sci., 63: 2497-2500.

[5] Carey, John B., and J. Brake (1987): Induced Molting as a Management Tool. Poultry Science and Technology Guide, No. 9, North Carolina Agricultural Extension Service.

[6] D. D. Bell (2003): Historical and current molting practices in the U.S. table egg industry, Poultry Sci., 82: 965970.

[7] Gary D. Butcher, D. V. M., Ph.D, and Richard Miles, Ph.D. Salmonella Control and Molting of Egg-Laying Flocks - Are They Compatible, Original publication date August (1994): Reviewed March 2011. Visit the EDIS website at http://edis.ifas.ufl.edu.

[8] Hurwitz, S., E. Wax, Y. Nisenbaum, M. Ben-Moshe, I. Plavnik (1998): The response of laying hens to induced moult as affected by strain and age. Poultry Sci. 77, 2231.

[9] Hussein, A. S. (1996): Induced moulting procedures in laying fowl. World's Poultry Sci. J., 52, 175-187.

[10] K. L. Landers, C. L. Woodward, X. Li, L. F. Kubena, D. J. Nisbet, S. C. Ricke (2005): Alfalfa as a single dietary source for molt induction in laying hens. Bio resource Technology, Volume 96, Issue 5, March 2005, Pages 565 -570 .

[11] Leek, K. (1982): Effect of forced moult period an post moult performance of leghorn hens. Poultry.Sci., 61, 1594-1598.

[12] Newman, S., S. Leeson (1998): Effect of housing birds in cages or ovary system on bone characteristics. Poultry. Sci., 77, 1492-1496.

[13] Maslić-Strižak Danka, Sokolović D., Ilić Živka, Miljković Biljana (1997): Druga proizvodna sezona komercijalnih nosilja. Zbornik radova IV savetovanje veterinara Republike Srpske, Teslić - Banja Vrućica, 227.

[14] Maslić-Strižak Danka, Sokolović D, Miljković Biljana, Ilić Živka (1998): Forsirano mitarenje konzumnih kokica držanih u kavezima. VII savetovanje živinara Jugoslavije, D. Milanovac, Lepenski Vir, 7-11.4.1998, Poster sekcija, Zbornik radova I, Živinarstvo, 4/5, XX

[15] Mingan Chacoct, Julie Roberts, Steve Walkden-Brown (1999): The significance of wet droppings in laying hens. Rural industries researsh and development corporation.

[16] Ocak, N., M. Sarica, G. Erener, A. V. Garipoğlu (2004): The effect of body weight prior to molting in Brown laying hens an egg yield and quality during second production cyclce. Int. J. Poultry Sci.,12, 768-772.

[17] S. Y. Park, W. K. Kim, S. G. Birkhold, L. F.Kubena, D. J. Nisbet and S. C. Ricke (2004): Induced moulting issues and alternative dietary strategies for the egg industry in the United States. World's Poultry Science Journal, Vol. 60, 196-204.

[18] Yildiz H., F. Alpay (2008): The effects of moulting diets on bone characteristtics and reproductive tracts in laying hens. Vet. Arhiv., 78, 227-234. 